\title{
Role of parents, teachers at home and school in prevention of female sexual abuse: an analysis
}

\author{
Anithathamaraiselvi A. Nainar, Sivapriya Ramasamy, Mekala Shanmugam*
}

Department of Obstetrics and Gynaecology, Government Dharmapuri Medical College and Hospital, Dharampuri, Tamil Nadu, India

Received: 08 October 2021

Revised: 08 December 2021

Accepted: 10 December 2021

\section{*Correspondence:}

Dr. Mekala Shanmugam,

E-mail: mekala.sks@gmail.com

Copyright: () the author(s), publisher and licensee Medip Academy. This is an open-access article distributed under the terms of the Creative Commons Attribution Non-Commercial License, which permits unrestricted non-commercial use, distribution, and reproduction in any medium, provided the original work is properly cited.

\section{ABSTRACT}

Background: Sexual assault is an act performed by one person on another without the person's consent or on a victim who is incapable of giving consent. The purpose of this article is to analyze the female sexual assault cases reported in one year -and the role of parents, teachers, at home and school in prevention of child sexual abuse.

Methods: Data of victims who were admitted in GDMCH in the department of obstetrics and gynaecology in the year 2020 were collected from the medico legal register retrospectively and analyzed.

Results: Age wise distribution showed $70 \%$ of cases were in the age group 15-19 years. 57\% of assaults were with consent and $43 \%$ without consent. $93 \%$ of the perpetrators were known to the victim. Around $48 \%$ of the assaults were multiple episodes by a single perpetrator. The place of assault in 39\% of cases was perpetrator's house, 35\% was in friend's or relative's house.

Conclusions: $86 \%$ of the victims were $<19$ years of age, hence, educational awareness services are to be given to high school students and teachers. School authorities and teachers should implement strict vigilance against improper use of the internet and mobile phones by the students. Most common location of assault was the perpetrator's house $(39 \%)$, followed by their friend's house $(22 \%)$. Hence parents should take every care to watch over the child and never leave them unsupervised.

Keywords: Child sexual abuse, Prevention, Victim, Perpetrator

\section{INTRODUCTION}

Sexual violence has a profound impact on physical and mental health. Sexual assault is an act performed by one person on another without the person's consent or on a victim who is incapable of giving consent. It includes penetrative or non-penetrative sexual intercourse, pornography, sexual harassment, commercial sexual exploitation. Apart from causing physical injury, it is associated with an increased risk of a range of sexual and reproductive health problems, with both immediate and long-term consequences. ${ }^{1-3}$ Its impact on mental health can be as serious as its physical impact, and may be equally long lasting. ${ }^{4,5}$ Deaths following sexual violence may be as a result of suicide, HIV infection or murderthe latter occurring either during a sexual assault or subsequently, as a murder of "honour" ${ }^{6,7}$ Sexual violence can also profoundly affect the social wellbeing of victims; individuals may be stigmatized and ostracized by their families and others as a consequence. ${ }^{8}$ Sexual assault include genital, oral or anal penetration by a part of the accused's body or by an object.9-11 This may include rape, forced vaginal, anal, or oral penetration, forced sexual intercourse, molestation, forced kissing, 
child sexual abuse or torture of the victim in a sexual manner. ${ }^{9}$ Although peno-vaginal penetration or attempted penetration of the anus or mouth without consent is increasingly being reported. ${ }^{10}$

The perpetrator usually ranges from a person close to the victim like a relative, neighbour, friend, schoolmate, teacher, caregiver, husband or guardian or a stranger. It has been found that women are more likely to be raped by someone they know than by someone they do not know. ${ }^{9}$ Most of the sexual assaults occur in the residence of the victim, the assailant or another individual's residence; other prevalent locations are streets, commercial buildings and inside a school building or property. ${ }^{9}$

\section{Objectives}

Objectives of current study are to analyze the female sexual assault cases and to determine the way to reduce the incidence of sexual abuse.

\section{METHODS}

It is a descriptive retrospective study. Government Dharmapuri medical college hospital in 2020. Selection criteria; all cases of female sexual assault victims presented to OG department. The data of victims were collected from medico legal registers and collected data was entered on a predesigned data sheet, tabulated and then statistically analyzed. Sample size was determined to be 90 cases.

\section{Inclusion criteria}

All cases of female sexual assault by both male and female perpetrators who presented to GDMCH in year 2020 were included.

\section{Exclusion criteria}

All male sexual assault cases and other assault cases presented to GDMCH were excluded.

\section{Statistical analysis}

Relevant data was analysed using SPSS for windows version 20.0.

\section{RESULTS}

\section{Victim's age distribution}

A total of 90 sexual assault cases were seen in GDMCH in OG department in a period of one year of which $86 \%$ of the victims were <19 years of age mostly $15-19$ years (70\%), age group between 10-14years and 20-30years were $11 \%$ each. Higher secondary school pupils were the most commonly assaulted victims.

\section{Profile of perpetrators}

All the perpetrators were male and majority of them were known to the victim $(93 \%)$ ranging from neighbour (29\%), love affair (27\%), neighbour (18\%) and friend (16\%). Only one perpetrator was involved in 89 cases (98.9\%).

\section{Pattern of clinical presentation}

Clinical presentations of victims during admission in GDMCH are described in TABLE4. Only $40 \%$ of victims were pregnant at the time of presentation $(1 \%$ molar pregnancy presented as bleeding PV, 6\% either spontaneously expelled or MTP done, 33\% continued their pregnancy), 53\% victims were non pregnant. $7 \%$ victims did not even attain menarche. Most commonly victims are brought to hospital by parents or relatives $(51 \%)$, police alone $(42 \%)$.

Table 1: Age distribution of victims $(n=90)$.

\begin{tabular}{|lll|}
\hline Victims age (years) & $\mathbf{N}$ & $\%$ \\
\hline $\mathbf{0 - 4}$ & - & - \\
\hline $\mathbf{5 - 9}$ & 4 & 5 \\
\hline $\mathbf{1 0 - 1 4}$ & 10 & 11 \\
\hline $\mathbf{1 5 - 1 9}$ & 63 & 70 \\
\hline $\mathbf{2 0 - 3 0}$ & 10 & 11 \\
\hline $\mathbf{3 1 - 4 0}$ & 3 & 3 \\
\hline
\end{tabular}

Table 2: Profile of perpetrators.

\begin{tabular}{|lll|}
\hline Perpetrator's relationship & N & $\%$ \\
\hline Known & 84 & 93 \\
\hline Relative & 26 & 29 \\
\hline Friend & 14 & 16 \\
\hline Love affair & 24 & 27 \\
\hline Co-worker & 4 & 4 \\
\hline Neighbor & 16 & 18 \\
\hline Unknown & 6 & 7 \\
\hline
\end{tabular}

Table 3: Number of perpetrators involved in sexual assault.

\begin{tabular}{|lll|}
\hline $\begin{array}{l}\text { Number of } \\
\text { accused }\end{array}$ & $\begin{array}{l}\text { Number of } \\
\text { victims }\end{array}$ & $\begin{array}{l}\% \text { of } \\
\text { survivor }\end{array}$ \\
\hline Single & 89 & $98.9 \%$ \\
\hline Multiple & 1 & 1.1 \\
\hline
\end{tabular}

Table 4: Clinical presentations of victim.

\begin{tabular}{|lll|}
\hline Presentation & N & $\%$ \\
\hline Upt positive & 36 & 40 \\
\hline antenatal & 30 & 33 \\
\hline Abortion & 5 & 6 \\
\hline Molar pregnancy & 1 & 1 \\
\hline Upt negative & 48 & 53 \\
\hline Not attained menarche & 6 & 7 \\
\hline
\end{tabular}




\section{Pattern of assault}

Total $95 \%$ of the sexual assault were of penetrative type. The most common location of sexual assault was in perpetrator's house $(39 \%)$, friend's house $(22 \%)$ followed by relative house (13\%). $57 \%$ of sexual assault was found to be with willingness of the victims and $51 \%$ of cases assault occurred multiple times before being identified. It shows ignorance about the consequences of sexual intercourse by victims. According to marital status of victims, most of the victims were married $(50 \%)$, unmarried $(44 \%)$ and the remaining were either divorced or widowed. Most common age group for marriage is 17 yrs (33\%), followed by 16 years (29\%) and 15 years (18\%). Awareness should be given about the eligible age for marriage in order to avoid child marriage.

Table 5: person accompanying victim during admission.

\begin{tabular}{|lll|}
\hline Brought by & N & $\%$ \\
\hline Mother/parent & 36 & 40 \\
\hline Relatives & 10 & 11 \\
\hline Police alone & 38 & 42 \\
\hline Others & 6 & 7 \\
\hline
\end{tabular}

Table 6: Type of assault.

\begin{tabular}{|lll|}
\hline Type of assault & N & $\%$ \\
\hline Penetrative & 86 & 95 \\
\hline Non-penetrative & 4 & 5 \\
\hline
\end{tabular}

Table 7: Place of assault.

\begin{tabular}{|lll|}
\hline Place of assault & N & $\%$ \\
\hline Public place & 8 & 9 \\
\hline Victims house & 4 & 5 \\
\hline Perpetrator house & 35 & 39 \\
\hline Friend house & 20 & 22 \\
\hline Rent house/ hotel & 11 & 12 \\
\hline Relative house & 12 & 13 \\
\hline
\end{tabular}

Table 8: Willingness of victim for sexual assault.

\begin{tabular}{|lll|}
\hline Willingness of victim & $\mathbf{N}$ & $\%$ \\
\hline With willingness & 51 & 57 \\
\hline Without willingness & 28 & 31 \\
\hline Not mentioned & 11 & 12 \\
\hline
\end{tabular}

Table 9: Single or multiple time assault by perpetrators.

\begin{tabular}{|lll|}
\hline No. of episodes & N & $\%$ \\
\hline Single & 28 & 31.3 \\
\hline Multiple & 46 & 51 \\
\hline Not mentioned & 16 & 17.7 \\
\hline
\end{tabular}

Table 10: Marital status of the victim.

\begin{tabular}{|lll|}
\hline Marital status & $\mathbf{N}$ & $\%$ \\
\hline Love marriage & 16 & 18 \\
\hline Arranged marriage & 29 & 32 \\
\hline Unmarried & 40 & 44 \\
\hline Divorced & 1 & 1 \\
\hline Widow & 4 & 5 \\
\hline
\end{tabular}

Table 11: Age of the victim at the time of marriage.

\begin{tabular}{|c|c|c|}
\hline Age at marriage (years) & $\mathbf{N}$ & $\%$ \\
\hline 13 & 2 & 4.4 \\
\hline 14 & 3 & 6.6 \\
\hline 15 & 8 & 18 \\
\hline 16 & 13 & 29 \\
\hline 17 & 15 & 33 \\
\hline$\geq 18$ & 4 & 9 \\
\hline
\end{tabular}

\section{DISCUSSION}

Among the victims, $86 \%$ were $<19$ years of age. Educational awareness services had to be given to high school students and teachers through social activists and social health teams. School authorities and teachers should implement strict vigilance against improper use of the internet and mobile phones by the students. The most common location of sexual assault was in perpetrator's house $(39 \%)$ and friend's house (22\%).

Hence elders and parents should monitor their children both male and female, closely about where and why they go out and keep vigilance on their activities. Most of assaults $57 \%$ were with willingness of victim, mostly eloped from school or working place it indicates ignorance and poor knowledge about the outcome of it, on victim's health and social problems. Most of the assailants were known to the victims for example neighbours, friends, acquaintances or relatives. This agrees with the finding in previous surveys. ${ }^{17-19}$ Only one assailant was involved in $98.9 \%$ of the cases with only one occurrence of more than one assailant. ${ }^{19-21}$ Most assaults were repeated multiple times before being identified by others. It indicates poor vigilance by parents not able to detect any behavioural changes of their children. Hence parents should be educated about the possibilities and occurrences $.97 \%$ of perpetrators were known to the victim - In a study conducted by Sarika Rawat et al \& Riggs et al find the same observation. ${ }^{15,16}$ We have to educate the students to be able to identify persons with wrong intentions and distinguish between good touch and bad touch. They should be bold enough and be communicative with parents and teachers. To encourage friendly relationships with parents and advise the children to inform any abnormal behavior to someone reliable as soon as the event occurs without any delay or feeling of guilt. 


\section{Limitations}

Limitations of current study were; authors only had access to data from the patients who come to the hospital. This leaves a big group of victims who do not report the assault. This will cause selection bias in the data. The data is recorded from the patient report. Since this is a sensitive topic there is a high chance of patients not telling the complete truth. This will cause response bias in the data

\section{CONCLUSION}

Sexual assault is a violation of basic human rights and assailants are known to the victim in most cases. All parents need to be mindful of the risk when leaving their children alone with anyone. Increased public awareness and preventive interventions are required especially among, at risk age group to enhance their safety. The children should be educated in terms of sexual problems not only scientifically but also in social and psychological aspects through teachers and social health teams. School teachers should be sensitized about the maximum occurrence of assault in the 15-19years age group. They should spend more time with these prone victims of these age groups.

\section{ACKNOWLEDGEMENTS}

Authors would like to thank the department head Dr. L. Malarvizhi and medical record staff of the teaching hospital and for their support during the study.

\section{Funding: No funding sources}

Conflict of interest: None declared

Ethical approval: The study was approved by the Institutional Ethics Committee

\section{REFERENCES}

1. Jewkes R, Abrahams N. The epidemiology of rape and sexual coercion in South Africa. Social Sci Med. 2002;55(7):1231-44.

2. Holmes MM. Rape related pregnancy: estimates and descriptive characteristics from a national sample of women. Am J Obstet Gynaecol. 2017;05:42-9.

3. Boyer D, Fine D. Sexual Abuse as a factor in adult pregnancy. Family Plan Prespect. 1992;24:4-11.

4. Briggs L, Joyce PR. What determines post-traumatic stress disorder symptomatology for survivors of childhood sexual abuse?. Child Abuse Neglect. 2015; 14:105-9.

5. Acierno R. Risk factors for rape, physical assault, and post-traumatic stress disorders in women: examination of differential multivariate relationships. J Anxiety Disord. 1999;13:541-63.
6. Miller M. Amodel explain the relationship between sexual abuse \& HIV risk among women. AIDS Care. 1999;11:3-20.

7. Mercy JA. Intentional injuries. In: Mashaly AY, Graitcer $\mathrm{PH}$, Youssef $\mathrm{ZM}$, eds. Injury in Egypt: analysis of injuries as a health problem. Cairo: Rose El Youssef New Presses; 1993:65-84.

8. Mollica RF, Son L. Cultural dimensions in the evaluation and treatment of sexual trauma: an overview. Psychiat Clin North Am. 1989;12:363-379.

9. Geidam AD, Njoku AE, Bako B. Prevalence and nature of sexual assault among female students in a tertiary institution in Maiduguri, Nigeria- A crosssectional study. Int J Health Res. 2010;3(4):199-203.

10. Akinsuli FM, Rabiu K, Olawepo T, Adewumi AA, Ottun TA, Akinola OI. Sexual assault in Lagos, Nigeria: a fiveretrospective review. BMC Women's Health. 2014; $14: 115$.

11. Lu MC, Lu JS, Halfin VP. Domestic violence and sexual assault. In: Decherney AH, Nathan L, Laufer N, Roman AS, eds. current diagnosis and treatment obstet gynecol. 11th ed. New York: McGraw Hill Medical; 2013:971-77.

12. Guidance for all doctors. Available at: www.gmcuk.org/guidance/archive/GMC. Accessed on 20 September 2021.

13. UK National guidelines on the management of adult and adolescent complainants of sexual assault 2011. Available at: https://www.bashhguidelines.org/ media/1079/4450.pdf. Accessed on 20 September 2021.

14. General Medical Council, Confidentiality: protecting and providing information. Available at: http://www.gmcuk.org/static/documents/content/ Confidentiality _core_2009. Accessed on 20 September 2021.

15. Rawat S, Guin G, Dadich R. A 5 year retrospective study - An overview of sexual assault survivors in NSCB medical college. BMC Women's Health. 2016:19:59-63.

16. Riggs N, Houry D, Long G, Markovchick V, Feldhaus KM. Analysis of 1076 cases of sexual assault. Ann Emerg Med. 2000:35(4):358-62.

17. Akinsuli FM, Rabiu k, Olawepo T, Adewumi AA. Sexual assault in Lagos, Nigeria: a five-retrospective review. BMC Women's Health. 2014;14:115.

18. Badejoko OO, Anyabolu HC, Badejoko BO, Ijarotimi AO, Kuti O, Adejuyigbe EA. Sexual assault in Ile-Ife, Nigeria. Niger Med J. 2014;55:254-9.

19. Margaret MMI, Mezie O, Folusho A. Sexual violence among female undergraduates in a tertiary institution in port-Harcourt: prevalence, pattern and health consequences. Afr J Reprod Health. 2014;18(4):79-85.

20. Ezechi OC, Musa ZA, David AN, Wapmuk AE, Idigbe IE. Trends and patterns of sexual assaults in Logaos, South-Western Nigeria. Pan Afr Med J. 2016;24:261.

21. Bugaje MA, Ogunrinde GO, Faruk JA. Child sexual abuse in Zaria, North Western Nigeria. Niger $\mathbf{J}$ Paed. 2012;39(3):110-4.

Cite this article as: Nainar AA, Ramasamy S, Shanmugam M. Role of parents, teachers at home and school in prevention of female sexual abuse: an analysis. Int J Reprod Contracept Obstet Gynecol 2022;11:165-8. 